BUDGETING : Journal of Business, Management and Accounting

Volume 2, Nomor 1, Desember 2020

e-ISSN: 2715-2480

p-ISSN: 2715-1913

DOI : https://doi.org/10.31539/budgeting.v2i1.1739

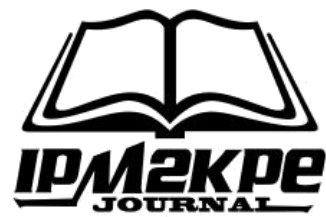

\title{
PERSEPSI KEMUDAHAN IMPLEMENTASI AKUNTANSI DAN MANFAAT INFORMASI AKUNTANSI PADA UMKM MELALUI PELATIHAN PENYUSUNAN LAPORAN KEUANGAN
}

\author{
Citra Dwi Agustin ${ }^{1}$, Dwi Cahyono ${ }^{2}$, Elok Fitriyah ${ }^{3}$ \\ Universitas Muhammadiyah Jember ${ }^{1,2,3}$ \\ citraagustin598@gmail.com ${ }^{1}$
}

\begin{abstract}
ABSTRAK
Tujuan penelitian ini adalah untuk mengetahui pengaruh pelatihan penyusunan laporan keuangan terhadap kemudahan pelaksanaan akuntansi dan manfaat informasi akuntansi pada UMKM di Kecamatan Panti. Metode yang digunakan pada penelitian ini adalah metode kuantitatif. Pengambilan sampel dilakukan dengan menggunakan purposive sampling. Pengumpulan data dilakukan dengan memberikan kuisioner yang merupakan bagian dari UMKM. Hasil penelitian menunjukkan bahwa terdapat perbedaan persepsi kemudahan implementasi akuntansi dan manfaat informasi akuntansi yang diajar menggunakan pelatihan penyusunan laporan keuangan. Simpulan, terdapat pengaruh yang signifikan pada pelatihan penyusunan laporan keuangan terhadap persepsi kemudahan implementasi akuntansi di UMKM di Kecamatan Panti. Namun pada pelatihan penyusunan laporan keuangan terhadap manfaat informasi akuntansi dan pelatihan penyusunan laporan keuangan terhadap persepsi kemudahan implementasi akuntansi dan manfaat informasi akuntansi tidak menunjukkan adanya pengaruh yang signifikan.
\end{abstract}

Kata Kunci: Akuntansi, Laporan Keuangan, Manfaat Informasi Akuntansi, UMKM

\section{ABSTRACT}

The purpose of this study was to determine the effect of financial report preparation training on the ease of implementing accounting and the benefits of accounting information at UMKM in Panti District. The method used in this research is quantitative method. The sample was taken by using purposive sampling. Data collection was carried out by means of a questionnaire which is part of the UMKM. The results showed that there were differences in perceptions of the ease of accounting implementation and the benefits of accounting information taught using financial reporting preparation training. In conclusion, there is a significant influence on the training in financial reporting on the perception of the ease of accounting implementation in UMKM in Panti District. However, training in preparing financial reports on the benefits of accounting information and training in preparing financial reports on the perception of ease of accounting implementation and the benefits of accounting information did not show a significant effect.

Keywords: Accounting, Financial Statements, Benefits of Accounting Information, $U M K M$ 


\section{PENDAHULUAN}

Usaha Mikro, Kecil dan Menengah (UMKM) adalah sebuah usaha yang bergerak di berbagai bidang usaha, diantaranya yaitu usaha perdagangan, usaha pertanian, usaha industri, usaha jasa dan lain-lain. Di Indonesia, UMKM merupakan salah satu cara yang efektif dalam mengurangi angka kemiskinan dan pengangguran. Berdasarkan data statistik, UMKM mewakili jumlah kelompok usaha terbesar.

UMKM merupakan kumpulan dari berbagai pelaku ekonomi terbesar dalam perekonomian di Indonesia serta menjadi faktor pertumbuhan ekonomi pasca krisis ekonomi. Selain menjadi kontribusi besar dalam pembangunan nasional, UMKM juga dapat menjadi peluang kerja yang cukup besar bagi tenaga kerja di Indonesia yang tentunya membutuhkan pekerjaan di sulitnya mencari pekerjaan di jaman globalisasi sekarang ini. Oleh karena itu dibutuhkan kesadaran kita untuk mengembangkan unitunit UMKM agar terciptanya kesejahteraan masyarakat.

UMKM menjadi perhatian lebih pemerintah untuk lebih lagi mengembangkan unit-unit UMKM. Keberhasilan UMKM mempunyai manfaat yang sangat besar khususnya untuk perekonomian Indonesia, membuat masyarakat pelaku UMKM lebih mandiri, membuat masyarakat lebih aktif dan kreatif dalam berpikir ide-ide terbaru untuk pengembangan usahanya. Namun dibalik itu semua, terdapat kendala atau tantangan yang dihadapi pelaku UMKM yaitu terkait dengan pengeolahan dana dan penyusunan laporan keuangannya karena pengolahan dana yang baik akan menjadi faktor penting dalam keberhasilan UMKM itu sendiri.

Menurut Suhairi (2004) UMKM memiliki kelemahan dalam penyusunan laporan keuangan. Hal ini disebabkan karena rendahnya pendidikan, kurangnya pemahamam terhadap Standar Akuntansi Keuangan (SAK), dan pelatihan penyusunan laporan keuangan. Selain itu, hasil penelitian ini sesaui dengan hasil penelitian yang dilakukan oleh Jati et.al., (2009) bahwa pelaksanaan pembukuan akuntansi untuk menghasilkan laporan keuangan merupakan hal yang masih sulit bagi UMKM. Keterbatasan pengetahuan pembukuan akuntansi, rumitnya proses akuntansi dan anggapan bahwa laporan keuangan bukanlah hal yang penting bagi UMKM.

Berdasarkan permasalahan di atas, perlu adanya upaya perbaikan pengembangan UMKM diantaranya membantu permodalan dengan kredit khusus yang mempermudah 
syarat-syarat untuk tidak memberatkan bagi pelaku UMKM, membantu peningkatan permodalan baik dari sektor finansial formal atau sektor finansial informal.

Perlindungan usaha baik usaha tradisional yang tergolong ekonomi rendah maupun usaha tinggi harus mendapat perlindungan dari pemerintah baik dari undangundang ataupun peraturan pemerintah. Pengembangan kemitraan yang saling membantu UMKM baik dari pangsa pasar dalam negeri maupun pangsa pasar luar negeri. Selain itu pelatihan pemerintah bagi UMKM baik dari aspek kewirausahaan, manajemen, administrasi dan pengetahuan tentang akuntansi atas pembukuan keuntungan dalam laporan keuangan juga sangat dibutuhkan.

Menurut penelitian yang dilakukan oleh Kurniawanysah (2016) UMKM sulit untuk melakukan pencatatan akuntansi karena keterbatasan yang dimiliki. Kebutuhan dalam penyelenggaraan catatan akuntansi dianggap hanya membuang waktu dan biaya. Sedangkan penelitian yang dilakukan oleh Kurniawati et al., (2012) menunjukkan bahwa sebagian besar UMKM di Kecamatan Panti sudah melakukan pencatatan atas penjualan, pembelian, persediaan, biaya gaji dan biaya lainnya. Sedangkan pelaporan yang dibuat meliputi laporan penjualan, pembelian, persediaan dan penggajian. Kendala yang menghambat UMKM dalam penerapan akuntansi antara lain adalah latar belakang pendidikan, belum pernah mengikuti pelatihan akuntansi dan belum ada kebutuhan terhadap penerapan akuntansi. Tujuan penelitian ini adalah untuk mengetahui persepsi pengetahuan akuntansi yang dimiliki oleh pelaku UMKM atas penyusunan laporan keuangan.

Berdasarkan data yang di peroleh dari Dinas Koperasi dan UMKM, jumlah UMKM yang diperoleh di Kecamatan Panti adalah 159, dimana data yang diperoleh dari Dinas Koperasi dan UMKM penelitian ini menggunakan kuesioner sebagai instrumen penelitian. Kelemahan yang dihadapi oleh UMKM diantaranya yaitu dalam bidang pemasaran, sumber daya manusia, operasional, administrasi dan keuangan.

Akses usaha kecil di Kecamatan Panti masih sangat kurang, sehingga mereka ketinggalan untuk memanfaatkan berbagai kebijakan pemerintah yang seharusnya dapat menjadi peluang bagi mereka dan dalam sisi pengelolaan keuangan pun masih sangat kurang. Dengan demikian tidak dapat dipungkiri bahwa usaha kecil masih banyak mengalami kesulitan dalam penggunaan informasi akuntansi dengan baik. Padahal dengan semakin ketatnya persaingan bisnis dalam era globalisasi ekonomi, hanya 
perusahaan yang memiliki keunggulan kompetitif dan kreatif yang akan mampu memenangkan persaingan. Berdasarkan permasalahan-permasalahan yang menjadi kunci pokok pelaku UMKM terhadap penggunaan informasi akuntansi dalam usaha yang dijalankan, maka peneliti tertarik untuk menganalisis pengaruh pelatihan penyusunan laporan keuangan terhadap persepsi kemudahan implementasi akuntansi dan manfaat informasi akuntansi pada UMKM di Kecamatan Panti.

\section{KAJIAN TEORI}

Pengaruh Penyusunan Laporan Keuangan terhadap Persepsi Kemudahan Implementasi Akuntasi

Akuntansi adalah proses pencatatan, pengukuran, pengklasifikasian, pengikhtisaran transaksi dan kejadian keuangan, pengintrepretasian atas hasilnya serta penyajian laporan. Standar Akuntansi Pemerintah (SAP) adalah prinsip-prinsip akuntansi yang diterapkan dalam menyusun dan menyajikan laporan keuangan pemerintah. SAP tersebut dibutuhkan dalam rangka penyusunan laporan pertanggung jawaban pelaksanaan APBN/APBD berupa laporan keuangan yang meliputi laporan realisasi anggaran, neraca, laporan arus kas dan catatan atas laporan keuangan.

Hasil penelitian Munizu (2010) menunjukkan bahwa faktor-faktor internal yang terdiri atas aspek sumber daya manusia, aspek keuangan, aspek teknik produksi/ operasional dan aspek pasar dan pemasaran mempunyai pengaruh yang signifikan dan positif terhadap kinerja Usaha Mikro dan Kecil (UKM). Adapun faktor-faktor eksternal terdiri atas aspek kebijakan pemerintah, aspek sosial budaya, ekonomi dan aspek peranan lembaga terkait mempunyai pengaruh yang signifikan dan positif terhadap kinerja UKM di Sulawesi Selatan. Temtime \& Pansiri (2004) melakukan penelitian pada 203 UKM di Bostwana. Hasil penelitiannya menunjukkan bahwa pengembangan sumber daya manusia, pengembangan organisasi, latar belakang manajer/pemilik, kepemipinan manajemen dan strategi bersaing merupakan komponen penting yang mempengaruhi kinerja UKM. 


\section{Pengaruh Penyusunan Laporan Keuangan terhadap Manfaat Informasi}

\section{Akuntansi}

Informasi akuntansi menunjuk pada fakta-fakta dan pengetahuan yang tersedia yang menjadi kebutuhan penting untuk seluruh kegiatan operasional dalam organisasi. Tanpa informasi yang tepat waktu dan akurat, baik para karyawan maupun manajer tidak akan dapat membuat keputusan secara efektif dan efisien (Suryo, 2007). Penelitian mengenai pengaruh informasi akuntansi dan motivasi karyawan terhadap keberhasilan UKM telah dilakukan oleh Permana (2014) dengan studi di UKM Knalpot di Purbalingga. Hasil penelitian menunjukkan bahwa laporan keuangan, perencanaan yang efektif dan pengambilan keputusan tidak berpengaruh terhadap keberhasilan UKM, sedangkan penentuan harga jual dan motivasi karyawan berpengaruh terhadap keberhasilan UKM.

Permana (2014) menyatakan bahwa pengaruh informasi akuntansi terhadap keberhasilan UKM bersifat positif. Penelitian tentang analisis perhitungan harga pokok produksi sepatu dengan metode full costing dilakukan oleh Rachmayanti (2011) menunjukkan bahwa UKM Galaksi menerapkan perhitungan harga pokok produksi masih sangat sederhana. Elemen biaya yang dihitung dengan menggunakan metoda perusahaan meliputi biaya bahan baku langsung, biaya tenaga kerja langsung dan biaya overhead pabrik (biaya lain-lain).

\section{METODE PENELITIAN}

Metode yang digunakan pada penelitian ini adalah metode kuantitatif yang merupakan suatu cara untuk menjawab masalah penelitian yang berkaitan dengan data berupa angka dan program statistik. Artikel ini akan menyajikan contoh-contoh riil pemaparan pendekatan dan jenis penelitian sampai dengan analisis data penelitian kuantitatif.

Untuk dapat menjabarkan dengan baik tentang pendekatan dan jenis penelitian, populasi dan sampel, instrumen penelitian, teknik pengumpulan data dan analisis data dalam suatu proposal atau laporan penelitian memerlukan pemahaman yang baik tentang masing-masing konsep tersebut. Hal ini penting untuk memastikan bahwa jenis penelitian sampai dengan analisis data yang dituangkan dalam proposal dan laporan penelitian telah sesuai dengan kaidah penulisan karya ilmiah yang dipersyaratkan. 
Artikel ini akan menyajikan contoh-contoh riil pemaparan pendekatan dan jenis penelitian sampai dengan analisis data penelitian kuantitatif. Populasi dalam penelitian ini adalah UMKM di Kecamatan Panti yang bergerak di bidang UMKM yang bermacam-macam. Sampel dalam penelitian ini dianalisis menggunakan metode purposive sampling menggunakan rumus Slovin dengan teknik pengambilan sampel nonprobability sampling yang berarti pengambilan sampel didasarkan pada kriteria tertentu.

Analisis kuantitatif merupakan metode analisis dengan angka-angka yang dapat dihitung maupun diukur. Analisis kuantitatif dimaksudkan untuk memperkirakan besarnya pengaruh secara kuantitatif dari perubahan satu atau beberapa kejadian lainnya dengan menggunakan alat analisis statistik yaitu dengan menggunakan aplikasi IBM SPSS 21.

\section{HASIL PENELITIAN}

\section{Pengujian Asumsi Klasik}

\section{Pengujian Multikolinearitas}

Tujuan dari uji multikolinearitas adalah menguji apakah dalam model regresi ditemukan adanya korelasi antar variabel independen. Model regresi yang baik seharusnya tidak terjadi kolinearitas diantara variabel independen (Ghozali,2011). Untuk mendeteksi ada atau tidak adanya multikolinearitas di dalam model regresi dalam penelitian ini dengan melihat nilai tolerance dan lawannya, variance inflation factor (VIF), indikator untuk menunjukkan adanya multikolinearitas adalah nilai dari tolerance $\leq 0,10$ atau sama dengan nilai $\mathrm{VIF} \geq 10$.

Tabel 1.

Uji Multikolinearitas

\begin{tabular}{cccc}
\hline No. & Variabel & Koefisien Beta & Standart Error \\
\hline 1 & Persepsi Kemudahan Implementasi & $-0,037$ & 0,040 \\
\hline 2 & Akuntansi (Y1) & 0,912 & 0,031 \\
\hline (Sumber: Data Diolah) & &
\end{tabular}

Hasil penelitian dan pengujian pada persepsi kemudahan implementasi akuntansi menunjukkan bahwa tidak terdapat gejala multikolinearitas pada variabel, dimana nilai standart error $(0,040)$ dan koefisien beta $(-0,037)$. Adapun pada manfaat informasi akuntansi juga tidak menunjukkan adanya gejala multikolinearitas. Hal tersebut dapat 
dilihat pada nilai koefisien beta $(0,912)$ dengan nilai standart error sebesar $(0,031)$, maka dapat dikatakan bahwa nilai standart error rendah dan menunjukkan tidak adanya multikolinearitas dari masing-masing variabel.

\section{Uji Homogenitas Varian}

Uji homogenitas varian dari data penelitian ini dilihat dari hasil uji Levene yang disajikan pada tabel berikut ini:

Tabel 2.

Uji Homogenitas Varian

\begin{tabular}{lccccc}
\hline \multicolumn{1}{c}{ Variabel } & Levene Statistic & df1 & df2 & Sig. \\
\hline $\begin{array}{l}\text { Persepsi Kemudahan } \\
\text { Akuntansi }\end{array}$ & Implementasi & 1.145 & 17 & 43 & 0.347 \\
\hline Manfaat Informasi Akuntansi & & & & \\
\hline $\begin{array}{l}\text { (Sumber: Data Diolah) } \\
\text { Sumber }\end{array}$ & & 17 & 43 & 0.000 \\
\hline
\end{tabular}

Berdasarkan data pada tabel 2, uji Levene menunjukkan bahwa hasil persepsi kemudahan implementasi akuntansi yaitu $\mathrm{F}=1.145$ dengan signifikasi 0.347. Adapun pada manfaat informasi akuntansi yaitu $\mathrm{F}=4.767$ dengan signifikasi 0.000. Bila ditetapkan taraf signifikasi 0,05, maka baik persepsi kemudahan implementasi akuntansi maupun manfaat informasi akuntansi menunjukkan harga yang $\mathrm{F}$ tidak signifikan karena signifikasi keduanya lebih besar dari 0,05. Artinya, baik angket maupun tes soal memiliki varian yang homogen, sehingga MANOVA bisa dilanjutkan.

\section{Uji Homogenitas Covarian}

MANOVA mempersyaratkan bahwa matriks varian/covarian dari variabel dependent sama. Uji homogenitas matriks variabel/covarian dilihat dari hasil uji Box's M. Apabila nilai Box's M signifikan maka hipotesis nol yang menyatakan bahwa matriks varian/covarian dari variabel dependent sama ditolak. Dalam kondisi ini analisis MANOVA tidak dapat dilanjutkan.

Tabel 3.

Uji Homogenitas Covarian

\begin{tabular}{ccc}
\hline & Uji Homogenitas Covarian \\
\hline Box's $M$ & 8.148 \\
F & .425 \\
df1 & 12 \\
df2 & 586.905 \\
Sig. & .954 \\
\hline
\end{tabular}

(Sumber: Data Diolah) 
Berdasarkan data tabel 3, diketahui bahwa nilai Box's $M=8.148$ degan signifikasi 0.954. Apabila ditetapkan taraf signifikasi penelitian 0,05, maka harga Box's $M$ yang diperoleh tidak signifikan karena signifikasi yang diperoleh lebih besar dari 0,05. Hal tersebut menunjukkan bahwa matriks varian/covarian dari variabel dependen adalah sama, sehingga analisis MANOVA dapat dilanjutkan.

Keputusan diambil berdasarkan analisis Pillae Trace, Wilk Lambada, Hotelling Trace, Roy's Largest Root. Jika hasil analisis menunjukkan harga F dengan nilai signifikan yang lebih besar dari 0,05, maka harga $\mathrm{F}$ adalah signifikan. Berdasarkan hasil uji, terdapat perbedaan persepsi kemudahan implementasi akuntansi dan manfaat informasi akuntansi yang diajar menggunakan pelatihan penyusunan laporan keuangan.

\section{PEMBAHASAN}

\section{Pengaruh Pelatihan Penyusunan Laporan Keuangan terhadap Persepsi Kemudahan Implementasi Akuntansi}

Hasil uji pengaruh pelatihan penyusunan laporan keuangan menunjukkan adanya pengaruh yang signifikan terhadap persepsi kemudahan implementasi akuntansi. Hal tersebut sejalan dengan hasil penelitian Harahap (2014) yang menunjukkan bahwa kemampuan menyusun laporan keuangan yang dimiliki pelaku UKM relatif rendah tetapi kinerja usaha yang responden peroleh tergolong cukup baik.

\section{Pengaruh Pelatihan Penyusunan Laporan Keuangan terhadap Manfaat Informasi}

\section{Akuntansi}

Hasil uji pengaruh pelatihan penyusunan laporan keuangan tidak menunjukkan adanya pengaruh yang signifikan terhadap manfaat informasi akuntansi. Hasil ini sejalan dengan penelitian Anggara \& Wibowo (2018) yang menunjukkan bahwa informasi akuntansi secara simultan berpengaruh terhadap keberhasilan usaha kecil. Adapun laporan keuangan secara parsial menunjukkan hasil yang tidak berpengaruh terhadap keberhasilan usaha kecil. Sementara perencanaan yang efektif, pengambilan keputusan, penentuan HPP dan penentuan harga jual berpengaruh terhadap keberhasilan usaha kecil. 


\section{Pengaruh Pelatihan Penyusunan Laporan Keuangan terhadap Persepsi}

\section{Kemudahan Implementasi Akuntansi dan Manfaat Informasi Akuntansi}

Berdasarkan hasil penelitian, pelatihan penyusunan laporan keuangan tidak berpengaruh signifikan terhadap persepsi kemudahan implementasi akuntansi dan manfaat informasi akuntansi. Hasil ini sejalan dengan penelitian Wahyudi (2009) yang menyatakan bahwa pendidikan manajer/pemilik, skala usaha, masa memimpin perusahaan, umur perusahaan dan pelatihan akuntansi manajer/pemilik merupakan halhal yang berpengaruh terhadap penggunaan informasi akuntansi pada UKM di Yogyakarta.

Suatu alat gambar kondisi usaha (apakah terjadi kemajuan atau kemunduran), pengambil keputusan yang akurat dan tepat waktu serta pertanggungjawaban pada manajemen dan yang terpenting secara mendasar adalah pemahaman makna laba atau rugi yang diperoleh dari hasil usahanya (Nurlaela, 2014). Hasil penelitian tersebut menunjukkan bahwa kemampuan menyusun laporan keuangan yang dimiliki pelaku UKM relatif rendah tetapi kinerja usaha yang responden peroleh tergolong cukup baik. Berdasarkan hasil uji hipotesis, kemampuan menyusun laporan keuangan yang dimiliki pelaku UKM tidak berpengaruh terhadap kinerja UKM.

\section{SIMPULAN}

Berdasarkan hasil penelitian yang telah dilakukan, maka dapat diambil kesimpulan bahwa terdapat pengaruh yang signifikan pada pelatihan penyusunan laporan keuangan terhadap persepsi kemudahan implementasi akuntansi di UMKM di Kecamatan Panti. Adapun pada pelatihan penyusunan laporan keuangan menunjukkan tidak adanya pengaruh yang signifikan terhadap manfaat informasi akuntansi. Begitupun juga analisis mengenai pengaruh pelatihan penyusunan laporan keuangan yang menunjukkan tidak adanya pengaruh yang signifikan terhadap persepsi kemudahan implementasi akuntansi dan manfaat informasi akuntansi di Kecamatan Panti. 


\section{DAFTAR PUSTAKA}

Anggara, S. K., \& Wibowo, R. Y. C. (2015). Pengaruh Informasi Akuntansi terhadap Keberhasilan Usaha Kecil dan Menengah Studi pada UKM Pengrajin Kulit di Bantul. Jurnal REKSA Rekayasa Keuangan Syariah dan Audit, 4(2), 190-212

Ghozali, I. (2011). Aplikasi Analisis Multivariate dengan Program SPSS. Semarang: Badan Penerbit Universitas Diponegoro

Harahap, Y. R. (2014). Kemampuan Menyusun Laporan Keuangan yang Dimiliki Pelaku UKM dan Pengaruhnya terhadap Kinerja UKM. Jurnal Riset Akuntansi dan Bisnis, 14(1), 66-76

Jati, H., Bala, B., \& Nisnoni, O. (2009). Menumbuhkan Kebiasaan Usaha Kecil Menyusun Laporan Keuangan. Jurnal Bisnis dan Usahawan, 2(8), 210-218

Kurniawansyah, D. (2016). Penerapan Pencatatan Akuntansi dan Penyusunan Laporan Keuangan Berdasarkan SAK ETAP pada UMKM Desa Gembongsari Kecamatan Kalipuro Kabupaten Banyuwangi. UNEJ e-Proceeding. Jember

Kurniawati, E. P., Nugroho, P. I., \& Arifin, C. (2012). Penerapan Akuntansi pada Usaha Mikro Kecil dan Menengah (UMKM). JMK, 10(2), 1-10

Munizu, M. (2010). Pengaruh Faktor-Faktor Eksternal dan Internal terhadap Kinerja Usaha Mikro dan Kecil (UMK) di Sulawesi Selatan. Jurnal Manajemen dan Kewirausahaan 12(1), 33-41

Nurlaela, S. (2014). Pengaruh Pengetahuan dan Pemahaman, Kesadaran, Persepsi terhadap Kemauan Membayar Pajak Wajib Pajak Orang Pribadi yang Melakukan Pekerjaan Bebas. Jurnal Paradigma, 11(2), 89-101

Permana, A. (2014). Pengaruh Persepsi Informasi Akuntansi dan Motivasi Karyawan terhadap Keberhasilan Usaha Kecil dan Menengah. Skripsi. Universitas Ahmad Dahlan

Rachmayanti, D. K. (2011). Analisis Perhitungan Harga Pokok Sepatu dengan Metode Full Costing (Studi Kasus pada UKM Galaksi, Kampung Kabandungan, Bogor). Skripsi. Institut Pertanian Bogor

Suhairi, T. (2004). Persepsi Akuntan terhadap Overload Standar Akuntansi Keuangan (SAK) bagi Usaha Kecil dan Menengah. Simposium Nasional Akuntansi 9. Padang

Suryo, A. (2007). Akuntansi untuk UKM, Edisi Kedua. Yogyakarta: Media Pressindo Temtime, Z. T., \& Pansiri, J. (2004). Small Business Critical Succes/Failure Factors in Developing Economies: Some Evidence from Bostwana. American Journal of Applied Sciences, 1(1), 18-25

Wahyudi, M. (2009). Analisis Faktor-Faktor yang Mempengaruhi Penggunaan Informasi Akuntansi pada Usaha Kecil dan Menengah (UKM) di Yogyakarta. Disertasi Doktoral. Universitas Diponegoro 